\title{
WANTI-WANTI POLITISASI BIROKRASI MENJELANG PILKADA 2020 DI NTT
}

\author{
Helenerius Ajo Leda \\ Gmail: henajo66@gmail.com \\ Staf Pengajar Ilmu Pemerintahan STPM Santa Ursula Ende
}

\begin{abstract}
Abstraksi
Artikel opini ini mengulas persoalan politisasi birokrasi yang masif terjadi saat momentum Pilkada yang berpijak pada data dan fakta yang terjadi di NTT menjelang Pilkada tahun 2020, bahwasannya birokrat (ASN) di NTT disinyalir tidak netral. Melalui artikel opini ini penulis berargumen bahwa, tampilnya para birokrat (ASN) secara terang-terangan mendukung salah satu kandidat dalam proses pilkadaa, menyebabkan birokrasi gampang di politisir oleh kekuatan-kekuatan politk tertentu. Pada titik ini birokrasi dijadikan kuda troya oleh kekuatankekuatan ekonomi politik penguasa demi mengakumulasi kepentigan jangka pendek maupun jangka panjang. Sehingga, upaya untuk mengembalikan fitrah birokrasi yang loyal pada profesi pelayanan publik yang berguna untuk menjabarkan kepentingan publik, membutuhkan perubahan total atas sistem dan struktur yang menyangga segala penyimpangannya yakni sistem ekonomi-politik kapitalistik yang berlaku hingga sekarang ini.
\end{abstract}

Katakunci: politisasi birokrasi, ekonomi-politik, kapitalisme, pilkada

\section{Pendahuluan}

Momentum pemilihan Kepala Daerah (Pilkada) tahun 2020 di NTT mengikutsertakan sembilan Kabupaten yakni, Malaka, Belu, TTS, Ngada, Manggarai, Manggai Barat, Sabu Raijua, Sumba Timur dan Sumba Barat (Kompas.com, 2020). Peforma politik lokal ini dipastikan akan memanas. Partai politik sebagai peserta yang hendak berlaga dalam medan pertarungan, mulai membentuk formasi dan formula dalam koalisi. Begitupun calon kandidat, entah itu yang incumbent maupun pendatang baru mulai merancang serangkaian strategi taktik politik.

Merespon momentum pilkada ini, pada awal Februari lalu Gubernur NTT memperingatkan secara tegas kepada birokrat (ASN) bahwa, "ASN harus netral dalam mengikuti pilkada 2020" (Kompas.com, 2020). Himbauan Gubernur tersebut secara eksplisit bermakna bahwa birokrasi tidak boleh dipolitisasi atau jangan politisasi birokrasi.

Pasalnya, jika merujuk pada Indeks Kerawanan Pemilu (IKP) yang baru-baru ini dirilis oleh Badan Pengawasan Pemilu 
(Bawaslu) Nasional, ASN di sejumlah daerah yang hendak meyelenggarakan Pilkada berpotensi tidak netral atau tidak bisa dinetralkan (bawaslu.go.id, 2020). Bentuk-bentuk kerawanan yang potensial terjadi diantaranya praktik politik uang (money politic), sogok menyogok, suap menyuap, gratifikasi, berita hoax ataupun lainnya, hingga mobilisasi birokrasi.

Nampaknya di Flores-NTT, salah satu potensi kerawanan pilkada yakni politisasi birokrasi sudah mencuat kepermukaan. Di Manggarai misalnya, Bawaslu setempat menetapkan enam ASN termasuk para pejabat di lingkup Pemkab Maggarai terbukti tidak netral dan memihak salah satu kandidat proses pilkada (Florespos, 21 Februari 2020). Kasus yang terjadi di Manggarai hanyalah satu kasus diantara sekian banyak kasus dalam sejarah politik lokal di NTT dan tidak menutup kemungkinan terhadap dimensi kerawanan lainnya akan terjadi, sebab dalam politik segala cara bisa dihalalkan.

Tampilnya para ASN secara terangterangan menjadi tim sukses salah satu kandidat dalam proses pilkada, menjadikan birokrasi gampang di politisir oleh kekuatan-kekuatan politk tertentu. Politik simbiosis mutualisme akan berlaku manaka kekuatan politik yang didukungnya menang dalam peperangan.

Selanjtnya mudah ditebak, pos-pos kekuasaan strategis dalam pemerintahan akan dijadikan sebagai reward politiknya, walau harus ditebus dengan hilangnya kedaulatan. Pada area ini, birokrasi ibarat berada pada medan magnet, area yang penuh dengan tarik menarik kekuatan akan kepentingan sesaat.

\section{Perdebatan Antara Politik Dan Birokrasi}

Para sarjana ilmu administrasi publik sudah lama membahas hubungan antara politik dan birokrasi. Woodrow Wilson (1887) dalam bukunya berjudul The Study of Administration mengatakan politik dan administrasi harus dipisahkan karena keduanya memiliki tugas yang berbeda. Padangan ini dikenal dengan dikotomi politik dan administrasi. Pemisahan antara politik administrasi dimaksudkan agar birokrasi publik dapat bekerja secara profesional melayani kepentingan umum (public interest) tanpa dibebani isu-isu politik (Kumorotomo, 2005).

Disisi lain, milasalnya Leonald D. White yang memiliki pandangan yang berbeda mengatakan bahwa, Ilmu administrasi publik hanya dapat dijalankan dengan efektif jika dikawinkan dengan teori politik-pemerintahan. Implikasi dari pendapat yang berbeda itu membentuk hubungan antara politik dan birokrasi baik dalam tataran keilmuan maupun praktis (Toha, 2005).

Dari pandangan yang berbeda tersebut memunculkan pertanyaan-pertanyaan yang mengugat netralitas birokrasi. Apakah birokrasi bisa netral dalam pemilu? Apakah birokrasi sebagai bagian dari kekuasaan dapat bertindak netral terhadap kekuatan-kekuatan politik?

Persoalan menyangkut netralitas birokrasi (ASN) terletak pada kondisi sturuktural yang menyangga bekerjanya birokrasi. Kondisi struktural inilah yang mendeterminasi posisi birokarasi sebagai bagian dari kekuasaan. 
Ada dua perspektif yang berupaya menjelaskan netralitas birokrasi, perspektif Weberian dan perspektif Marxis. Perspektif Weberian berpandangan bahwa, birokrasi harus netral agar mereka dapat betindak secara rasional. Dengan rasionalitas maka birokrasi akan memiliki tubuh yang sehat dan mampu melayani mayarakat dengan baik. Jika ada kekuatan politik yang mempengaruhi kehendak birokrasi, berarti rasionalitas terancam. Sehingga kepentingan politik harus disingkirkan, dan birokrasi harus bekerja dalam senyap terhadap kekuatan-kekuatan politik. Sedangkan perspektif Marxis menganggap bahwa tidak ada birokrasi yang netral. Menurut pandangan ini birokrasi adalah alat atau instrumen kekuasaan. Birokrasi dibentuk sebagai alat kepentingan kelas penguasa untuk mendominasi, mendisiplikan, mengontrol hingga menghisap kelas-kelas sosial yang tidak berkuasa (Arifi Nofianto, 2019).

Menurut penulis, segala hal ihwal politik dan birokrasi tidak bekerja diruang hampa, tapi bekerja dalam tubuh masyarakat manusia secara historis. Ia tidak diunduh dari ruang maya, lalu diinstal pada ruang nyata. Namun ia bekerja dalam konteks dimana manusia itu hidup yang berkaitan secara dialektis dengan sistem dan struktur sosial, ideologi, budaya masyarakat.

Pada arus pemikiran ini, penulis sepakat dengan Karl Marx yang membagi tubuh masyarakat terbagi menjadi dua bagian struktur. Pertama, struktur bangunan atas, yang disebutnya sebagai suprastruktur, bagian ini mencakup ideologi, hukum, birokrasi pemerintahan, politik, keluarga, agama. Sedangkan bagian yang kedua adalah struktur bangun bawah yang ia sebut sebagai infrastruktur yang mencakup ekonomi (cara produksi). Perubahan pada setiap bagian atas struktur tubuh masyarakat selalau di kondisikan secara dielektik oleh struktru bangun bawah.

Jika menggunakan konsepsi Marx tersebut maka watak politik dan birokrasi yang menyimpang itu sebenarnya dikondisikan/ditentukan oleh kekuatankekuatan ekonomi (kapital) yang dimonopoli oleh sekelompok kecil orang. Dalam konteks saat ini, dimana tatanan ekonomi kapitalistik yang dominan akan menentukan mekanisme kerja politik dan birokrasi. Politik dan birokrasi akan berkerja seturut laju gerak tubuh ekonomi yang dikuasai dan berpihak pada kekuatankekekuatan kapital.

\section{Politisasi Birokrasi Dan Birokrasi Politik}

Dalam sejarah hubungan politik dan birokrasi di Indonesia setidaknya ada dua hal yang menonjol yakni birokrasi politik dan politik birokrasi. Birokrasi politik artinya menempatkan birokrasi sebagai mesin politik yang mendominasi pembuatan keputusan hingga kontrol politik birokrat pada kelompok kepentingan. Sedangkan politik birokrasi artinya menciptakan birokrasi yang tanggap dan patuh pada kepentingan politik jangka pendek penguasa (Sutoro Eko, 2004). Model birokrasi politik dan politik birokrasi tersebut dapat kita saksikan dalam perjalan sejarah republik ini sejak kolonialisme sampai reformasi kini.

Pada intinya politik dan birokrasi dijadikan kuda troya oleh kekuatan-kekuatan ekonomi politik penguasa demi mengakumulasi kepentigan dengan membangun menara oligarki. Para 
birokrat, politisi dan penyelenggara negara adalah aparatus yang bertindak dengan kepentingan ekonomi politik. Mereka mencancang taktik multi bentuk untuk mengawetkan kekuasaan dan mengakumulasi keuntungan ekonomi.

Di Flores, Seperti yang dijelaskan oleh Emilianus Yakob Sese Tolo (2016: 181) dalam artikelnya yang berjudul Akumulasi Melalu Perampasan dan Kemiskinan di Flores, bahwa proses politisasi birokrasi pemerintahan di Flores, terjadi lewat politik persekongkolan maha dasyat antara pemegang kekuasaan baik di ranah birokrasi, politik, dan Gereja Katolik. Melalui taktik politik saling menunggangi dan perkoncoan, mereka menjarah sumber daya ekonomi, melakukan korupsi, memanipulasi anggaran publik, proyek fiktif dan sebagainya.

Bukti-bukti tentang terjerembabnya biroraksi dalam praktik politik praktis, kongkalikong dengan kekuatan ekonomi politik penguasa di NTT, dapat kita saksikan melaui data-data statistik berbagai modus korupsi yang kian fantastis. Hasil rilis kasus korupsi oleh KPK misalnya, di NTT didominasi korupsi disektor pengadaan barang dan jasa sekitar 80 persen (Antaranews.com, 2019). Sektor ini paling laris manis melibatkan birokrasi, pihak swasta (kapitalis lokal) dan politisi, yang membentuk relasi kuasa oligarkis dalam tubuh penyelenggaraan pemerintahan. Relasi kuasa yang demikian membuat agenda demokratisasi dan remofrasi dikorupsi hingga saat ini.

\section{Penutup}

Kita muak dengan proses pilkada yang selalu didandani dengan segala macam pencintraan berkedok tipu daya dan daya tipu dengan mempolitisasi birokrasi atau manjadikan birokrasi sebagai alat politik. Kita mendambakan birokrasi yang loyal pada profesi pelayanan publik yang berguna untuk menjabarkan kepentingan publik. Dambaan akan watak birokrasi yang demikian tentunya menjadi sebuah imajinasi kolektif. Mengembalikan fitrah birokrasi kejalannya membutuhkan perubahan total atas sistem dan struktur yang menyangga segala penyimpangannya. Rakyat perlu membangun kesadaran yang kritis dengan membendung simpul-simpul gerakan sosial politik yang mempuni. Merebut biro-kratos kembali ke tangan demos.***

\section{Daftar Pustaka}

Eko, Sutoro. 2004. Menantang Akuntabilitas Publik Dari Medan Warga (Pembelajaran Pelaksanaan Program SIAP II (Strengthening Integrity and Accountability Program) di Enam Wilayah Kabupaten/Kota. Jakarta Timur: Yappika.

Kumorotomo, Wahyudi. 2005. Akuntabilitas Birokrasi Publik: Sketsa pada Masa Transisi. Yogyakarta: Kerjasama antara MAPUGM dan Pustaka Pelajar.

Novianto, Arif. 2019. Mempertanyakan Netralitas Birokrat dalam Pemilu: antara Sistem Sosial, Kekuasaan, \& Budaya Patron-Client. Yogyakarta: Buletin IGPA (Institute of Governance and Public Affairs) Edisi Maret 2019. Magister Administrasi Publik Universitas Gajah Mada. 
Thoha, Miftah. 2005. Dimensi-dimensi Prima Ilmu Administrasi Negara. Jakarta: Rajawali Pers.

Tolo, Emilianus Yakob Sese. 2016. Akumulasi Melalu Perampasan dan Kemiskinan di Flores. Masyarakat: Jurnal Sosiologi. Universitas Indonesia

https://kupang.compas.com > g...Gubernur NTT: ASN Harus Netral Selama Pilkada 2020 - Kompas.com

https://www.bawaslu.go.id > berita 25

Februari, Bawaslu Akan Luncurkan Indeks Kerawanan Pilkada 2020 | Badan Pengawas...

https://www.florespost.co $>$ diduga-t... Diduga Tidak Netral, Bawaslu Manggarai Periksa 7 ASN | Florespost.co

https://www.antaranews.com > k... Kasus korupsi di NTT didominasi pengadaan barang dan jasaANTARA News 